\title{
Screening and Isolation of Pigment Producers and Non-pigment Producers Actinomycetes from Rhizosperic Soil Sample
}

\author{
V.P. Dhawane* and S.N. Zodpe \\ Department of Microbiology, Shri Shivaji College Akola-444001(M.S), India \\ *Corresponding author
}

\section{A B S T R A C T}

Keywords

Rhizospheric soil,

Pigment producer

Actinomycetes,

Antibiotic and

Antigonastic activity.

Article Info

Accepted:

17 April 2017

Available Online:

10 May 2017
Actinomycetes are Gram negative and Gram positive filamentous and sporulating bacteria and represent a ubiquitous group of microbes widely distributed in natural ecosystem around the world. For the isolation of Actinomycetes various methods can be performed on the basis of different sources and media. In the present study, 8 Actinomycetes were isolates from rhizospheric soil from Karanja (Lad) District wahism. Out of 8 Actinomycetes isolates, two isolates was found to be sensitive against all isolates and shows very excellent zone of inhibition. Antagonastic activity against human pathogens like, $S$. aureus, E. coli, $P$. aeruginosa and $P$. vulgaris, was also carried out. From the complete observation it was noticed that isolate $\mathrm{N}$ obtained from neem soil and $\mathrm{H}$ from Hibiscus soil is having excellent antagonistic activity in controlling all the test pathogens.

\section{Introduction}

Rhizosphere is a unique biological niche with diverse microflora comprising bacteria, fungi, protozoa and algae. It is defined as the soil adjacent to an influenced by plant root exudates (Gonzales-France et al., 2009). Actinomycetes form a large and important segment of the microflora of most natural environments. Soils, freshwater, lake and river bottoms, manures and compost contain an abundance of these organisms (Wright 1956a, Wright 1956b).

Actinomycetes are diverse group of Gram positive bacteria that usually grow by filament formation. They belong to the order Actinomycetales (Super kingdom: Bacteria,
Phylum: Firmicutes, Class: Actinobacteria, Subclass: Actinobacteridae) (Okami and Hotta 1988).

Actinomycetes species synthesize a numerous natural metabolites with diverse biological activity such as antibiotics. Antibiotics of Actinomycetes origin evidence a wide variety of chemical structure, including amino glycosides, antracyclines, $\quad \beta$-lactams, nucleosides, peptides, polyenes, actinomycins and tetracycline (Barrios-Gonzalez et al., 2005). Antibiotics have been used in many fields including agriculture, veterinary and pharmaceutical industry (Kavitha, Vijayalakshmi, 2007). Actinomycetes has 
diverse clinical effects and are active against many pathogenic organisms Actinomycetes and their bioactive compound show antibacterial and anti microbial against various pathogens and multi drug resistant pathogens e.g. Vancomycin-Resistant Enterococci, Methicillin-Resistant Staphylococcus aureus, Shigella dysenteriae, Klebsiella sp. and Pseudomonas aeruginosa etc (Bhatnagar and Kim, 2011; Saadoun et al., 1999; Selvameenal et al., 2009 and Servin et al., 2008).

Actinomycetes also synthesize and excrete dark pigments, melanin or malanoid (Zenova 1965; Arai and Mikami 1972; Amal et al., 2011). These melanin compounds are irregular, dark brown polymers having radio protective and antioxidant properties that can effectively protect the living organisms from ultraviolet radiation (Romero-Martinez et al., 2012). Melanins are frequently used in medicine, pharmacology and cosmetics preparation (Quadri and Asgar, 2012).

Rhizosphere soil of these plants may be an attractive actinomycetes source, able of producing novel secondary metabolites. Catalase, Chitinase and Urease enzymes also produce from actinomycetes (Wutthithamavet, 1997).

\section{Materials and Methods}

The present work has been undertaken to study the "Screening and Isolation of Pigment Producers and Non-pigment Producers Actinomycetes from Rhizospheric Soil Sample". The experiments were carried out adopting the following Materials and Methods.

\section{Collection of soil sample}

Rhizospheric soil sample were collected from various medicinal plant. Total 8 soil samples were screened for isolation of Actinomycetes.
There sample were mainly collected from various region of Karanja (Lad) Dist. Washim. The soil samples were collected from a depth of 10 inches from surface area in commercially available sterile polythene bags.

\section{Pre-treatment of the soil sample}

The soil samples were pretreated in order to reduce the proportion of other microorganisms than Actinomycetes. The soil samples were dried for about $50-60^{\circ} \mathrm{C}$ for 5 - 10 minutes (Selvamohan et al., 2016).

\section{Isolation of actinomycetes}

Each soil sample (1g) was suspended in 100 $\mathrm{ml}$ sterile distilled water, then homogenized by vortex mixing, mixtures were allowed to settle and serial ten folds dilutions up to $10^{-4}$ were prepared by using sterile distilled water. Isolation was carried out on Actinomycetes Isolation agar plates by spreading. The plates were incubated at $37^{\circ} \mathrm{C}$ for $24 \mathrm{hrs}$. After attaining a powdery growth, the colonies were observed, based on the colour and Morphological differences, colonies were selected and restreaked on Actinomycetes Isolation Agar medium. Further the culture is prescrved for antagonistic studies ( $\mathrm{T}$. Selvamohan et al., 2016).

\section{Characterization of actinomycetes}

The potent Actinomycetes isolates selected from primary screening were characterized by Morphological, biochemical and physiological method. The morphological method consists of macroscopic and microscopic characterization. Macroscopically the Actinomycetes isolates were differentiated by their colony characters, e.g. size, shape, colour, consistency etc. For the microscopy, the isolates were grown by cover slip culture method (Kawato and Sinobu, 1979). 


\section{In vitro screening of Isolates for antagonism}

Actinomycetes isolates were tested for their antibacterial activity against bacterial pathogens namely Escherichia coli, Pseudomonas aeruginosa, Proteus vulgaris and Staphylococcus aureus. The antibacterial activity was carried out by Agar Well diffusion method. The Actinomycetes isolates isolated from the rhizosphere soil of medicinal plants were spotted on the prepoured nutrient agar plates already having a lawn of indicator test bacteria on it. Plates were incubated at $37^{\circ} \mathrm{C}$ for $24 \mathrm{hrs}$ and observed for clear zone formation around the well. Antibacterial activity was expressed in terms of diameter $(\mathrm{mm})$ of clear zone produced around the well at $37^{\circ} \mathrm{C}$ for $24 \mathrm{hrs}$. (Mohinder Kaur et al., 2015).

\section{Antibiotic susceptibility test}

The antibiotic sensitivity of test strains was determined by the standard Disc diffusion method against a number of antibiotics. All antibiotic discs were purchased from the Himedia Pvt, Ltd. (Bombay, India). The antibacterial activity was performed according to CLST, USA guidelines on Mueller Hinton Agar Well Medium using diffusion method (Anitha et al., 2009; EIMehalawy et al., 2005).

\section{Partial purification of the pigments from actinomycetes}

The natural pigment producing Actinomycetes colonies obtained in the present study were inoculated in $100 \mathrm{ml}$ of yeast extract broth and incubate at $37^{\circ} \mathrm{C}$ for $24 \mathrm{hrs}$. After incubation the pigmented broth was centrifuged at $2000 \mathrm{rpm}$ for $15 \mathrm{~min}$ and the supernatant was recovered. This step was repeated twice (Velmurugan et al., 2009). Supernatant taken out and measure the optimum density at various wavelength range.

\section{Results and Discussion}

In the present study 8 actinomycetes strains were isolated from Rhizospheric soil sample of different medicinal plants from various region of Karanja (lad) Dist. Washim. It was based on the colony Morphology and Pigmentation.

Isolation of Actinomycetes has always been faced with difficulties in comparison to their competitors like other bacteria (William and Corss, 1971).

All the obtained isolates were found to be Gram negative organism. However, results reported by Taradevi Gurung et al., (2009) showed that both Gram negative and Gram positive bacteria were obtained during their study. This might be due to the morphological difference between those two types of microorganisms (Nakaido and Vaara, 1985).

Out of 8 isolates two were found to be pigment producers Actinomycetes i.e. isolate $\mathrm{A} 2$ and $\mathrm{H}$. Isolate A2 shows pink colour whereas isolate $\mathrm{H}$ shown bluish green colour on Actinomycetes Isolation Agar. According to Teli et al., (2000) reported that in their study the pigments such as pink, yellow, deep pink, greenish brown and brown diffused in the Kuster's broth were partially purified.

The cultural characters of the Actinomycetes strain T1, T2, A1, A2, N, H, Tu, and $\mathrm{Ni}$ on Actinomycetes isolation agar medium were studied. It was noticed that Actinomycetes Isolation Agar medium favoured the rapid growth of powdery colonies within incubation period at $37^{\circ} \mathrm{C}$ for $24 \mathrm{hrs}$. Similarly Nakaido and Vaara (1985) showed that the screening revealed that more isolates were active against gram positive bacteria than Gram negative bacteria. The biochemical study indicates that Actinomycetes, isolates showed fermentation of Lactose and Maltose with acid and gas production where as in case 
Glucose and mannitol rest of other isolates shows only acid production but no gas production. During the biochemical studies it was noticed that Methyl Red Test was positive for all the isolates except for isolate $\mathrm{N}$ whereas all isolates utilizes citrate showing positive test. Beside this only two isolates i.e. A1 and A2 shows VP test positive and indole test was found to be negative for all isolates.

The enzyme production ability of isolates was studied. The results revealed that actinomycetes shows positive catalase and oxidase activity whereas only two $\mathrm{N}$ and $\mathrm{H}$ isolates shows gelatin liquification, According to Martin et al., (2008) the biochemical studies indicate that all Actinomycetes, isolates can be used a potent source for the enzymes like amylase, lipase, caseinase and gelatinase. The enzymes are very much useful for their saprophytic mode of life.

Many actinomycetes have been isolated from various natural sources, as well as in plant tissues and rhizospheric soil Biological function of Actinomycetes mainly depend on sources from which the bacteria are isolated (Sharmin, 2005).

Totally 8 Actinomycetes isolates were tested against 5 different antibiotics i.e. Amoxycillin (10 mg), Erythromycin (15 mg), Tetracycline (30 mg), Ciprofloxacin (10 mg), Amoxyclave (30 $\mathrm{mg}$ ) and the results were recorded in terms of zone of inhibition in $\mathrm{mm}$. The most surprising result was obtained in case of Ciprofloxacin. Ciprofloxacin found to be sensitive against all isolates and shows very excellent zone of inhibition ranging from 18 $27 \mathrm{~mm}$.

However, Amoxycillin is sensitive only against A1 isolates and for rest of isolates it was resistant. Similar pattern of result was observed in case of Erythromycin which was found to be sensitive only against isolates A1 and $\mathrm{Ni}$ and shows resistant towards other isolates.
Amoxyclave shows intermediate type of activity but active against isolate A1. Hence overall results revealed that all the antibiotics were sensitive against isolate A1 obtained from rhizospheric soil of Alovera.

Antibiotics susceptibility pattern were tabulated (Table 1, Graph 1). From the above results Ciprofloxacin antibiotic showed excellent activity. Erythromycin and Tetracycline showed good to moderate activity whereas Amoxycillin and Amoxyclave showed no activity. According to Sandeepta et al., (2015) that the Bacillus strain were observed to inhibit growth of Gram positive and Gram negative test organisms such as Escherichia coli, Staphylococcus aureus, Klebsiella spp., and Pseudomonas spp. indicating that antibiotic produced by strains is a broad spectrum antibiotic. Interestingly, the isolated strain showed resistance to tetracycline.

Antibacterial activities were performed by disc-diffusion assay and effectiveness was measured by zone of inhibition on bacterial culture plates.

The isolates Actinomycetes spp. against test bacteria was tabulated in Table No. 2, from the above result $S$. aureus showed activity for T2 isolate showing zone of $30 \mathrm{~mm}$ and very less activity $(6 \mathrm{~mm})$ for $\mathrm{Ni}$ isolate was observed. E. coli showed moderate type of activity for all the isolates. In case of $P$. aeruginosa best activity was shown by the $\mathrm{N}$ and $\mathrm{H}$ isolate i.e. $25 \mathrm{~mm}$ and $28 \mathrm{~mm}$ respectively and for rest of other isolates moderate activity was shown by the same organism. It was noticed that isolate $\mathrm{N}$ and $\mathrm{H}$ again shows excellent activity towards $P$. vulgaris.

From the complete observation it was noticed that Isolate $\mathrm{N}$ obtained from Neem soil and $\mathrm{H}$ from Hibiscus soil is having excellent 
antagonistic activity in controlling all the test pathogens. Arifuzman et al., (2010) studied soil samples of Karanjal region of Sundarbans of Bangladesh and 55 actinomycetes were isolated and screened for antibacterial activity. Out of 55 isolates 20 isolates $(36.36 \%)$ were active against the test organisms. Dehnad et al., 2010 studied the antibacterial activity of Streptomyces isolates from soil samples of west of Iran.

Table.1 Antibiotic susceptibility pattern of obtained isolates

\begin{tabular}{|c|c|c|c|c|c|c|c|c|c|c|}
\hline \multirow{2}{*}{ Isolates } & \multicolumn{8}{|c|}{ Zone of inhibition (diameter in mm) } \\
\cline { 2 - 13 } & \multicolumn{2}{|c|}{ Amoxycillin } & \multicolumn{2}{|c|}{ Erythromycin } & \multicolumn{2}{|c|}{ Tetracycline } & \multicolumn{2}{c|}{ Ciprofloxacin } & \multicolumn{2}{c|}{ Amoxyclave } \\
\hline $\mathrm{T}_{1}$ & $12 \mathrm{~mm}$ & $\mathrm{R}$ & $13 \mathrm{~mm}$ & $\mathrm{R}$ & $15 \mathrm{~mm}$ & $\mathrm{I}$ & $20 \mathrm{~mm}$ & $\mathrm{~S}$ & $16 \mathrm{~mm}$ & $\mathrm{I}$ \\
\hline $\mathrm{T}_{2}$ & -- & - & $10 \mathrm{~mm}$ & $\mathrm{R}$ & $10 \mathrm{~mm}$ & $\mathrm{R}$ & $26 \mathrm{~mm}$ & $\mathrm{~S}$ & -- & - \\
\hline $\mathrm{A}_{1}$ & $26 \mathrm{~mm}$ & $\mathrm{~S}$ & $26 \mathrm{~mm}$ & $\mathrm{~S}$ & $23 \mathrm{~mm}$ & $\mathrm{~S}$ & $26 \mathrm{~mm}$ & $\mathrm{~S}$ & $22 \mathrm{~mm}$ & $\mathrm{~S}$ \\
\hline $\mathrm{A}_{2}$ & -- & - & $12 \mathrm{~mm}$ & $\mathrm{R}$ & $10 \mathrm{~mm}$ & $\mathrm{R}$ & $24 \mathrm{~mm}$ & $\mathrm{~S}$ & -- & - \\
\hline $\mathrm{N}$ & $12 \mathrm{~mm}$ & $\mathrm{R}$ & $14 \mathrm{~mm}$ & $\mathrm{R}$ & $15 \mathrm{~mm}$ & $\mathrm{I}$ & $25 \mathrm{~mm}$ & $\mathrm{~S}$ & $16 \mathrm{~mm}$ & $\mathrm{I}$ \\
\hline $\mathrm{H}$ & -- & - & $10 \mathrm{~mm}$ & $\mathrm{R}$ & -- & - & $27 \mathrm{~mm}$ & $\mathrm{~S}$ & -- & - \\
\hline $\mathrm{Tu}$ & $11 \mathrm{~mm}$ & $\mathrm{R}$ & $12 \mathrm{~mm}$ & $\mathrm{R}$ & $16 \mathrm{~mm}$ & $\mathrm{I}$ & $18 \mathrm{~mm}$ & $\mathrm{~S}$ & $10 \mathrm{~mm}$ & $\mathrm{R}$ \\
\hline $\mathrm{Ni}$ & -- & - & $23 \mathrm{~mm}$ & $\mathrm{~S}$ & $16 \mathrm{~mm}$ & $\mathrm{I}$ & $21 \mathrm{~mm}$ & $\mathrm{~S}$ & -- & - \\
\hline
\end{tabular}

Where, -- = No zone of inhibition, $\mathrm{R}=$ Resistance, $\mathrm{S}=$ Sensitive, $\mathrm{I}=$ Intermediate

Table.2 Isolates strains of actinomycetes activities against pathogenic bacteria i.e. Escherichia coli, Staphycoloccus aureus, Pseudomonas aeruginosa and Proteus vulgaris

\begin{tabular}{|c|c|c|c|c|}
\hline \multirow{2}{*}{ Isolates } & \multicolumn{4}{|c|}{ Zone of inhibition (diameter in mm) } \\
\cline { 2 - 5 } & E. coli & S. aureus & P. aeruginosa & P. vulgaris \\
\hline $\mathrm{T}_{1}$ & $15 \mathrm{~mm}$ & $10 \mathrm{~mm}$ & $15 \mathrm{~mm}$ & $10 \mathrm{~mm}$ \\
\hline $\mathrm{T}_{2}$ & $10 \mathrm{~mm}$ & $30 \mathrm{~mm}$ & $10 \mathrm{~mm}$ & $8 \mathrm{~mm}$ \\
\hline $\mathrm{A}_{1}$ & $16 \mathrm{~mm}$ & $5 \mathrm{~mm}$ & $1 \mathrm{~mm}$ & $1 \mathrm{~mm}$ \\
\hline $\mathrm{A}_{2}$ & $1 \mathrm{~mm}$ & $11 \mathrm{~mm}$ & $10 \mathrm{~mm}$ & $10 \mathrm{~mm}$ \\
\hline $\mathrm{N}$ & $15 \mathrm{~mm}$ & $15 \mathrm{~mm}$ & $25 \mathrm{~mm}$ & $20 \mathrm{~mm}$ \\
\hline $\mathrm{H}$ & $21 \mathrm{~mm}$ & $6 \mathrm{~mm}$ & $28 \mathrm{~mm}$ & $22 \mathrm{~mm}$ \\
\hline $\mathrm{Tu}$ & $5 \mathrm{~mm}$ & $15 \mathrm{~mm}$ & $15 \mathrm{~mm}$ & $20 \mathrm{~mm}$ \\
\hline $\mathrm{Ni}$ & $3 \mathrm{~mm}$ & $6 \mathrm{~mm}$ & $24 \mathrm{~mm}$ & $4 \mathrm{~mm}$ \\
\hline
\end{tabular}


Table.3 Optical density of two pigment producer Actinomycetes at different ranges

\begin{tabular}{|l|c|c|c|c|c|c|}
\hline \multirow{2}{*}{ Isolate } & \multicolumn{7}{|c|}{ Wave length (nm) } \\
\cline { 2 - 7 } & $\mathbf{4 2 0}$ & $\mathbf{4 4 0}$ & $\mathbf{5 2 0}$ & $\mathbf{5 6 0}$ & $\mathbf{6 2 0}$ & $\mathbf{6 6 0}$ \\
\hline $\mathrm{A} 2$ & 0.762 & 0.689 & 0.476 & 0.342 & 0.342 & 0.332 \\
\hline $\mathrm{H}$ & 1.184 & 1.032 & 0.648 & 0.570 & 0.492 & 0.490 \\
\hline
\end{tabular}

Fig.1 Antibiotic susceptibility pattern of obtained isolates

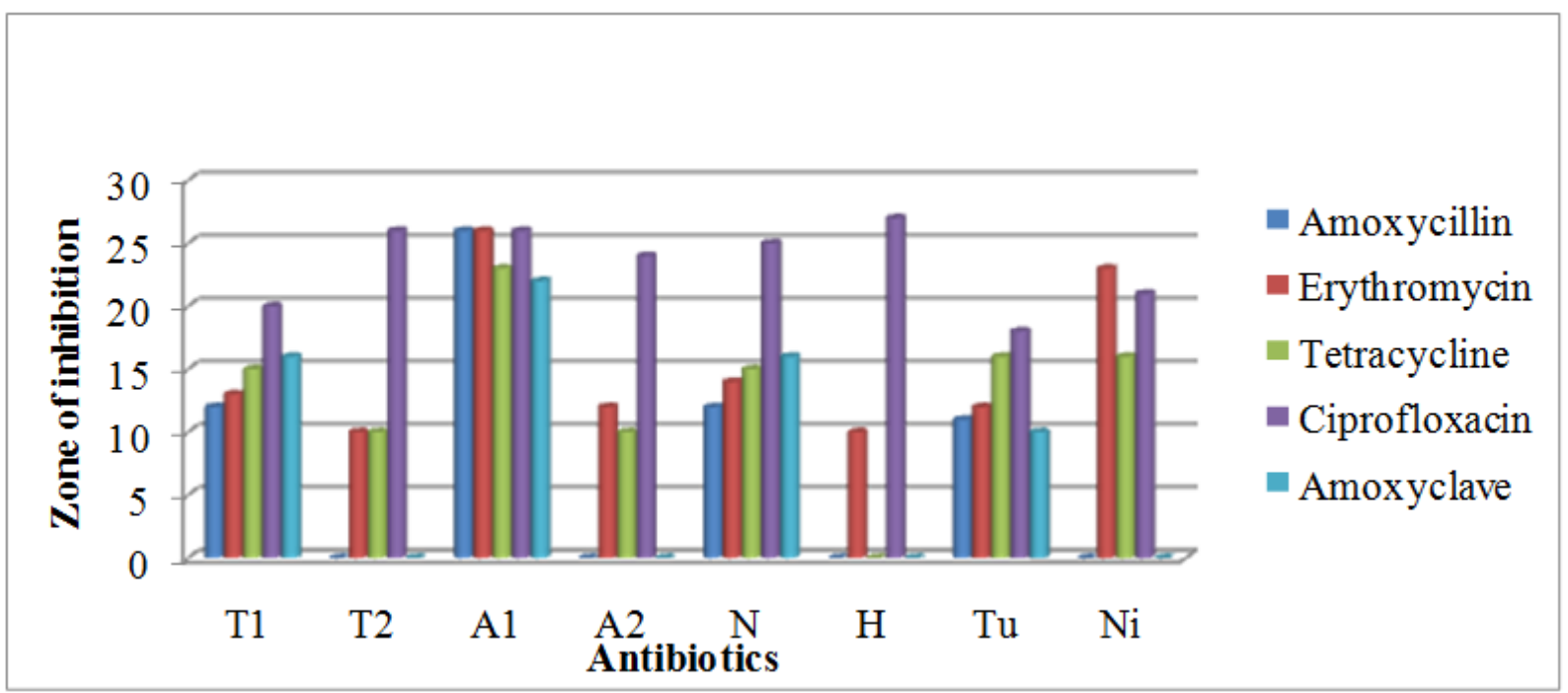

Fig.2 Activities of isolated actinomycetes strains against test bacteria

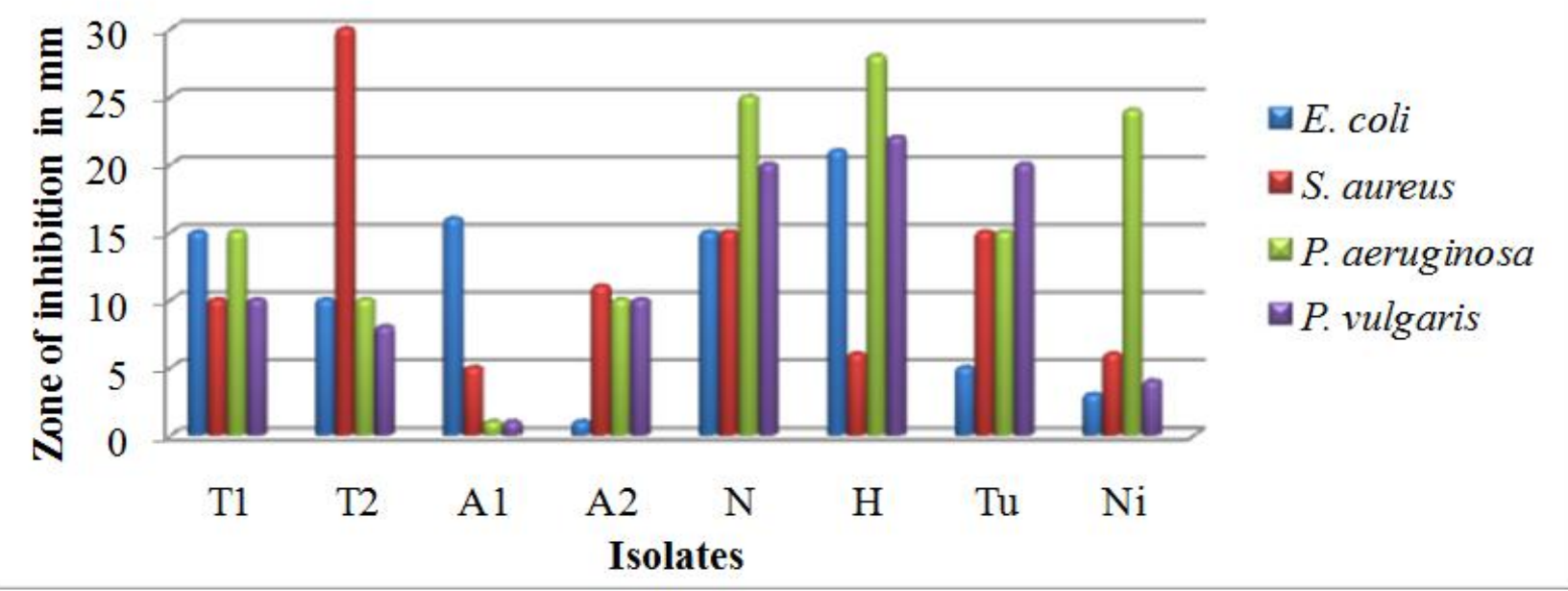


Fig.3 Optical density of two pigment producer Actinomycetes at different ranges

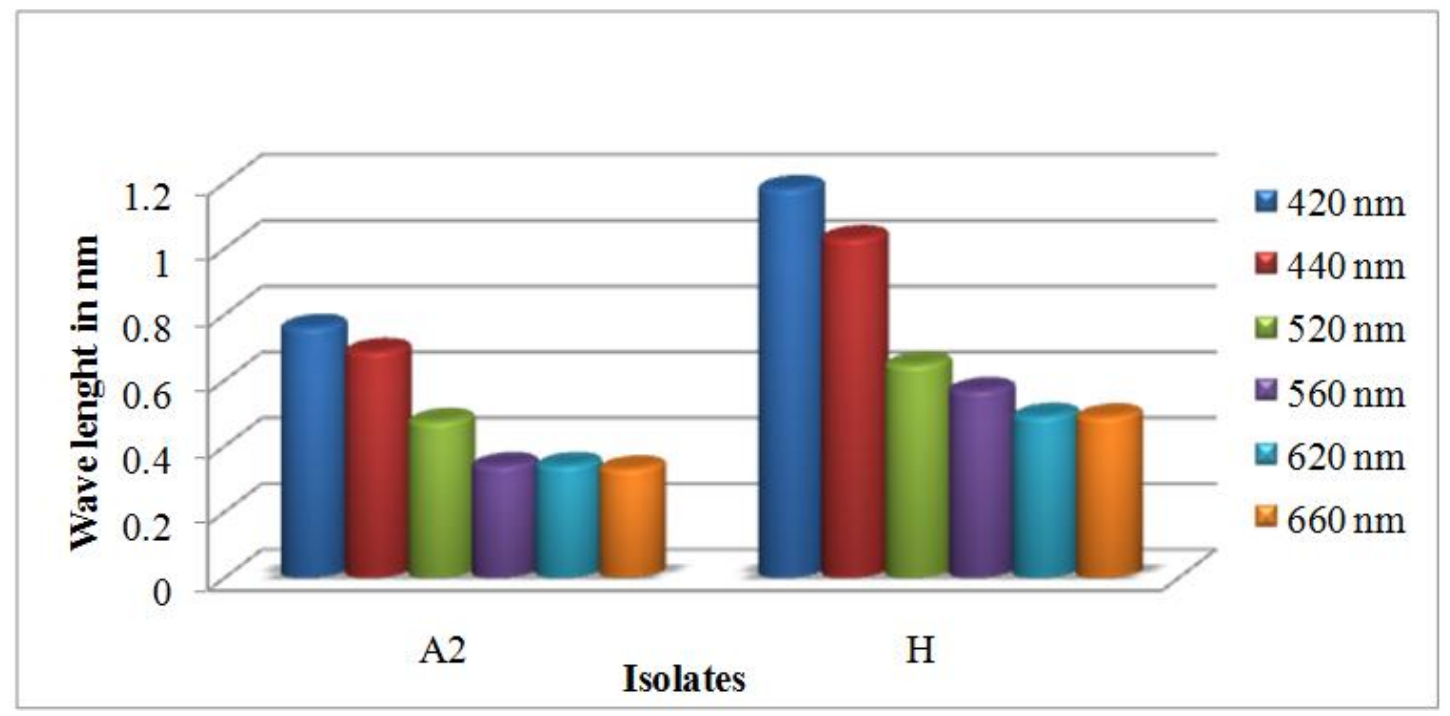

Zakir et al., (2002) showed that the antibacterial activities were studied by well plate method. All the Actinomycetes isolates showed antibacterial activity against five pathogenic organisms.

Similarly in previous study Jarallah (2014) isolated Strpetomyces KLG 13 from agricultural soil in Hillah city that possess high antibacterial activity against E. coli, $P$. aeruginosa, S. aureus and Marganella spp.

The Actinimycetes isolates showed pigmentation of optimum density measure at all wave length. Table No. 3 leads to Optimum density results (Fig. 3). It was observed that for Isolate $\mathrm{H}$ higher activity was observed at all wave length. The highest activity was measured at $420 \mathrm{~nm}$ followed by $440 \mathrm{~nm}$ for isolate $\mathrm{H}$. Other isolate showed moderate activity. Very less activity was shown by A2 isolate for 560, 620 and $660 \mathrm{~nm}$

Teli et al., (2000) stated that the production and evaluation of microbial pigments as textile colourants is currently being investigated. Similarly Ramasamy Amsaveni et al., (2015) reported that natural colours or biocolours have numerous applications in textile as well as in food industries as colouring agents.

Further characterization of Actinomycetes and their products for utilization in Plant Biotechnology, Urban Waste Management, Environmental Biotechnology and some other applications yet to be done, the potential number of metabolites from Actinomycetes may be discover in future.

\section{Acknowledgement}

The authors gratefully acknowledge the instrumentation facilities for this work provided by college (Shri Shivaji College of Arts, Commerce and Science, Akola) through DST - FIST.

\section{References}

Amal, A.M., Abeer, K.A., Samia, H.M., Nadia, A.H., Ahmed, K.A., El-Hennawi, H.M. 2011. Selection of Pigment (Melanin) production in Streptomyces and their application in Printing and Dyeing of Wool Fabrics. Res J. Chem. Sci., 1: 22 8 . 
Anitha, A., Rebeeth, M. 2009. In vitro antifungal activity of Streptomyces griseus against phytopathogenic fungi of tomato field. Acad. J. Plant Sci., 2(2): 119 -123 .

Arai, T., Mikami, Y. 1972. Choromogenecity of Streptomyces. Appl. Microbiol., 23: 402 - 6.

Arifuzzaman, M., Khatun, M.R. and Rahman, H. 2010. Isolation and screening of actinomycetes from Sundarbans soil for antibacterial activity. African $J$. Biotechnol., 9(29): 4615- 4619.

Barrios-Gonzalez J., F.J. Fernandez, A. Tomosini and A. Megia. 2005. Secondary metabolies production by solid -state fermentation. Malaysian $J$. Microbial., 1: 1-6.

Bhatnagar I., Kim, S.K. 2011. Immense essence of excellence: marine microbial bioactive compounds. Marine drugs, 8(10): 2673 2701.

Dehand, A., Parsa, L., Bakshi, R., Soofiani, S.A. and Mokhtarzadeh. A. 2010. Investigation antibacterial activity of Streptomycetes isolates from soil samples, West of Iran. African $J$. Microbiol. Res., 4(14): 1542 - 1549.

El-Mehalawy, A.A., Abd-Allah, N.A., Mohamed, R.M., Abu-Shay, M.R. 2005. Actinomycetes antagonizing plant and human pathogenic fungi 2005; II. Factors affecting antifungal production and chemical characterization of the active components. Int. J. Agric. Biol., 7(2): 188-196.

Gonzalez-Franco, A.C., Robles-Hernandez, L., Nunez-Barrios, A., Strap, J.L., CrawFord, D.L. 2009. Molecular and cultural analysis of seasonal actinomycetes in soils from Artemisia tridentate habitate. Int. J. Experimental Bot., 78: 83 - 90.

Kavitha, Vijayalakshmi, M. 2007. J. Appl. Sci. Res., 3(12): 2026 - 2029.

Kawato, M. and R. Shinobu. 1959. A simple technique for the microscopical observation. Memoirs of the Osaka University Liberal Arts and Education, 8:114.

Martin, K., Nathan, M., Sharon, E., Wellingon,
E.M.H. $2000 . \quad$ Actinomycetes. Encyclopedia of Microbiol., Vol.I, 2nd Edn., 28-41.

Mohinder Kaur, Sheetal Rana and Ranjna Sharma. 2015. Screening and evaluation of antimicrobial activity of actinomycetes isolated from rhizosphere of Heracleum candicans. Int. J. Farm Sci., 5(1): 83-89.

Nokaido, H. and M. Vaara. 1985. Molecular basis of bacterial outer membrane permeability. Microbiol. Rev., 49(1): 132.

Okami, Y. and K. Hotta. 1988. Search and discovery of new antibiotics. In: Actinomycetes in biotechnology (Eds. M. Good Fellow, S.T. Williams and M. Mordarski. Academic press, London pp. 37-67.

Quadri, R.S., Asgar, D. 2012. Detection of melanin producing thermoalkaliphilic Streptomyces from limestone quarries of the Deccan traps. World J. Sci. Technol., 2: $08-12$.

Ramasamy Amsaveni, Muthusamy Sureshkumar, Govindasami Vivekanandhan, Veluswamy Bhuvaneshwari and Manokaran Kalaiselvi. 2015. Screening and isolation of pigment producing Actinomycetes from soil samples. Int. J. Biosci. Nanosci., 2(2): 24-28.

Romero-Martinez, R., Wheeler, M., GuerreroPlata, A., Rico, G., Torres-Guerrero, H. 2000. Biosynthesis and functions of melanin in Sporothrix schenckii. Infect Immun., 68: 3696 - 703.

Saadoun, I., Hameed, K.M., Moussauui, A. 1999. Characterization and analysis of antibiotic activity of some aquatic actinomycetes. Microbios, 99(394): 173 179.

Sandeepta Burgula, M.V.S., Sandhya, E., Ramyakrishna, P., Divya, Anoor Pawan Kumar, Karthik Rajkumar, Emad Yazein. 2015. Isolation of antibiotic producing bacteria from soil. Int. J. Appl. Biol. Pharmaceutical Technol., 6(1): 46 - 51.

Selvameenal, L., Radhakrishnan, M., Balagurunathan, R. 2009. Antibiotic 
pigment from desert soil actinomycetes; biological activity, purification and chemical screening. Indian J. Pharma Sci., 71(5): 499 - 504.

Selvamohan T., N.K. Parameswaran, S. Abisha Felcy. 2016. Isolation of Actinomycetes from different soils for analysing the antagonistic activity against pathogens. Int. J. Adv. Res. Biol. Sci., 3(8): 124-131.

Servin, J.A., Herbold, C.W., Skophammer, R.G., Lake J.A. 2008. Evidence excluding the root of the tree of life from the actinobacteria. Mol. Biol. Evol., 25(1): 14.

Sharmin, S., Md Towhid Hossain and M.N. Anwar. 2005. Isolation and characterization of a protease producing bacteria Bacillus amonvivorus and optimization of some factors of culture conditions for protease production, $J$. Biol. Sci., 5(3): 358-362.

Tara Devi Gurung, Chringma Sherpa, Vishwanath Prasad Agrawal and Binod Lekhak. 2009. Isolation and Characterization of Antibacterial Actinomycetes from Soil Samples of Kalapatthar, Mount Everest Region, Nepal J. Sci. Technol., 10: 173 - 182.

Teli, M.D., Roshan, P., Pardeshi, P.D. 2000. Natural Dyes: Classification, chemistry and Extraction methods, Colourage, 4348 .
Velmurugan, P, Kamala-Kannan, S, Balachandar, V., et al. 2009. Natural pigment extraction from five filamentous fungi for industrial applications and dyeing of leather, Carbohydrate Polymers, doi:10.1016/j.carbpol.2009.07.058.

Williams, S.T. and T. Cross. 1971. Actinomycetes, Appl. Microbiol., 4 Academic Press.

Wright, J.M. 1956a. The production of antibiotics in soil. 111. Production of gliotoxin in wheat straw buried in soil. Annals of Appl. Biol., 44: 461-66.

Wright, J.M. 1956b. The production of antibiotics in soil. IV. Production of antibiotics in coats of seeds sown in soil. Annals of Appl. Biol., 44: 561-66.

Wutthithamavet, W. 1997. Thai traditional medicine. Revised ed. Odean Store Press, Bangkok, Thailand, ISBN 9742773858, pp: 155

Zakir, S.M., Nazinin, A., Khatune, Z., Sultana, S., Shah, A., Bhuiyan, G., Sadik, M., Arteruzzaman, C., Gopur, M. A., Rahman, M.D. 2002. In vitro antibacterial activity of metabolites isolated from Streptomyces species. Biotechnol., 1(2-4): 100 - 106.

Zenova, G.M. 1965. Melanoid pigments of Actinomycetes. Mikrobiologiia, 34: 278 83.

\section{How to cite this article:}

Dhawane, V.P. and Zodpe, S.N. 2017. Screening and Isolation of Pigment Producers and Nonpigment Producers Actinomycetes from Rhizosperic Soil Sample. Int.J.Curr.Microbiol.App.Sci. 6(5): 1570-1578. doi: https://doi.org/10.20546/ijcmas.2017.605.171 